\title{
KARAKTERISTIK MORFOMETRIK DAN POLA PERTUMBUHAN IKAN KETING [Mystus nigriceps (Valenciennes 1840)] DI HILIR SUNGAI CIMANUK PROVINSI JAWA BARAT
}

\section{MORPHOMETRIC CHARACTERISTIC AND GROWTH PATTERN OF KETING [Mystus nigriceps (Valenciennes 1840)] IN DOWNSTREAM OF CIMANUK RIVER WEST JAVA PROVINCE}

\author{
Titin Herawati, Muthia Nada Safitri, Junianto, Herman Hamdani, Ayi Yustiati, \\ Atikah Nurhayati \\ Program Studi Perikanan, Fakultas Perikanan dan Ilmu Kelautan Universitas Padjadjaran, \\ Bandung, Jawa Barat \\ E-mail: titin.herawati@unpad.ac.id \\ (diterima Januari 2021, direvisi Mei 2021, disetujui Juli 2021)
}

\begin{abstract}
ABSTRAK
Ikan keting [Mystus nigriceps (Valenciennes 1840)] merupakan ikan yang memiliki nilai ekonomis di beberapa daerah. Secara morfologi, termasuk dalam kelompok ikan bersungut (catfish) dari Ordo Siluriformes dan Famili Bagridae. Penelitian ini bertujuan untuk menganalisis ciri morfometrik, pola pertumbuhan, dan faktor kondisi ikan keting yang berada di hilir Sungai Cimanuk. Metode yang digunakan adalah metode survei dengan teknik pengambilan sampel purposive sampling di tiga stasiun riset, yaitu Desa Ujungjaya Kabupaten Sumedang (St.1), Desa Palasari Kabupaten Majalengka (St.2), dan Desa Jatibarang Kabupaten Indramayu (St.3). Penelitian dilakukan pada bulan Agustus hingga September 2020. Hasil penelitian menunjukkan ikan keting yang tertangkap pada Stasiun 1 dan Stasiun 2 memiliki karakteristik morfometrik yang sama, pola pertumbuhan bersifat allometrik negatif $(b<3)$ dengan nilai $b$ di Stasiun 1 adalah 2,958 dan di Stasiun 2 adalah 1,966 yang artinya pertambahan panjang lebih cepat dibandingkan pertambahan bobot. Faktor kondisi (K) di Stasiun 1 relatif lebih tinggi daripada di Stasiun 2, yaitu antara 0,99 - 1,16 dengan rata-rata sebesar 1,08; sedangkan di Stasiun 2 antara 0,98 - 1,06 dengan nilai rata-rata K sebesar 1,03. Ikan dari Stasiun 3 tidak dilakukan analisis lanjutan karena tidak memenuhi persyaratan statistik.
\end{abstract}

Kata kunci: allometrik negatif, Mystus nigriceps, pola pertumbuhan, faktor kondisi.

\begin{abstract}
Keting fish [Mystus nigriceps (Valenciennes 1840)] is a fish that has economic value in several areas. Morphologically, it is included in the group of catfish from the order Siluriformes and family Bagridae. This study aims to analyze the morphometric characteristics, growth patterns, and condition factors of keting fish in the downstream of the Cimanuk River. The survey method was applied with purposive sampling technique in three research stations, namely Ujungjaya Village, Sumedang Regency (St.1), Palasari Village, Majalengka Regency (St.2), and Jatibarang Village, Indramayu Regency (St.3). The study was conducted from August to September 2020. The results showed that the keting fish caught at Station 1 and Station 2 had the same morphometric characteristics, the growth pattern was negative allometric $(b<3)$ with the value of $b$ at Station 1 being 2,958 and at Station 2 is 1.966, which means the increase in length is faster than the increase in weight. The condition factor $(\mathrm{K})$ at Station 1 is relatively higher than at Station 2, which is between $0.99-1.16$ with an average of 1.08 ; while at Station 2 between $0.98-1.06$ with an average $\mathrm{K}$ value of 1.03 . Fishes from Station 3 were not further analyzed because they did not meet statistical requirements.
\end{abstract}

Keywords: Mystus nigriceps, growth pattern, condition factor.

\section{PENDAHULUAN}

Di perairan umum darat Indonesia keanekaragaman jenis ikan tawar termasuk tinggi. Peraturan Menteri Kelautan dan Perikanan no 9 tahun 2020 mengelompokkan Wilayah Pengelolaan Perikanan di Perairan Darat menjadi 3 kawasan karena sumber daya ikan di perairan memiliki karakteristik ekologi, limnologi, dan zoogeografi yang berbeda, yaitu Wilayah Pengelolaan Perikanan Negara Republik Indonesia di Perairan Darat (WPPNRIPD) 41 (kawasan paparan sahul), 42 (Kawasan Wallace), dan 43 (kawasan paparan sunda). Kottelat et al. (1993) dan Haryono (2017) melaporkan bahwa di wilayah Indonesia Barat dan Sulawesi sedikitnya terdapat 900 jenis. Di perairan wilayah Jawa Barat yang termasuk bagian dari kawasan paparan sunda 
sudah teridentifikasi sebanyak 185 spesies dari 59 famili (Herawati et al. 2019). Herawati et al. (2020) melakukan penelitian di bagian hilir Sungai Cimanuk dan menemukan 9 jenis ikan dari 5 famili, yaitu Cyprinidae adalah paray (Rasbora argyrotaenia), benteur (Barbodes binotatus), beureum panon (Systomus orphoides); Osphronemidae adalah sepat (Trichopodus pectoralis); Anabantidae adalah betok (Anabas testudineus); Siluridae adalah lais (Ompok bimaculatus); serta Bagridae adalah senggal (Mystus gulio), singaringan (Mystus singaringan), dan keting (Mystus nigriceps).

Keting merupakan ikan yang memiliki nilai ekonomis di beberapa daerah, dan secara morfologis termasuk kelompok ikan bersungut (catfish) dari Ordo Siluriformes dan Famili Bagridae. Keting memiliki beberapa nama lokal sesuai daerah ditemukannya, yaitu ikan keting, ingir-ingir, dengan nama umum twospot catfish. Habitat ikan keting ditemukan dalam jumlah besar di sungai arus lambat dengan substrat berlumpur. Untuk kawasan Asia, Froese \& Pauly (2021) menyebutkan bahwa ikan keting tersebar di Indonesia, Malaysia, dan Daerah Aliran Sungai Mekong (Mekong basin). Di Indonesia, penyebarannya diketahui berasal dari Sumatra Selatan (Sekumpang) dan sejumlah drainase di Pulau Jawa (Bengawan Solo, Cimanuk, Citanduy, Ciujung, Kali Brantas) (Ng 2002). Kottelat et al. (1993) juga melaporkan penyebaran ikan keting di paparan sunda dan Thailand.

Status konservasi ikan keting dalam IUCN Red list untuk spesies terancam punah termasuk kategori Least Concern (LC) (Ng 2019). Ikan ini hidup secara demersal di air tawar dengan $\mathrm{pH}$ antara $6,0-7,0$, suhu antara $20{ }^{\circ} \mathrm{C}-26{ }^{\circ} \mathrm{C}$, dan bersifat potamodromus (Riede 2004; Riehl \& Baensch 1991).
Sungai Cimanuk merupakan satu di antara tiga sungai besar yang ada di Jawa Barat dan terbesar kedua setelah Sungai Citarum (Sjafei et al. 2001). Bagian hilir sungai merupakan daerah bagian dengan substrat permukaan berupa endapan pasir halus sampai kasar, lumpur, endapan organik, dan jenis endapan lainnya yang sangat labil (Herawati et al. 2020).

Ukuran baku yang biasa digunakan dalam menganalisis ciri morfometrik pada ikan, antara lain panjang, tinggi, dan lebar badan. Tiap spesies ikan mempunyai ukuran berbeda-beda yang disebabkan oleh umur, jenis kelamin, dan lingkungan hidupnya. Faktor lingkungan yang dimaksud antara lain makanan, suhu, $\mathrm{pH}$, dan salinitas (Surawijaya 2004). Ciri meristik meliputi apa saja pada ikan yang dapat dihitung antara lain jarijari dan duri pada sirip, jumlah sisik, serta jumlah sisik pada linea lateralis dan ciri ini menjadi tanda dari spesies (Affandi et al. 1992).

Selama dalam pertumbuhan, tiap pertambahan bobot material ikan akan berpengaruh terhadap penambahan Panjang tubuh, namun perbandingan liniernya akan tetap. Hal tersebut dianggap bahwa bobot ikan yang ideal sama dengan pangkat tiga dari panjangnya dan berlaku untuk ikan kecil atau besar. Apabila terdapat perubahan bobot tanpa diikuti oleh perubahan panjang atau sebaliknya akan menyebabkan perubahan nilai perbandingan tersebut (Effendi 2002). Faktor kondisi yang tinggi menunjukkan ikan dalam perkembangan gonad, sedangkan faktor kondisi rendah menunjukkan ikan kurang mendapat asupan makanan. Faktor kondisi juga akan berbeda tergantung jenis kelamin ikan, musim, lokasi penangkapan, serta dipengaruhi oleh tingkat 

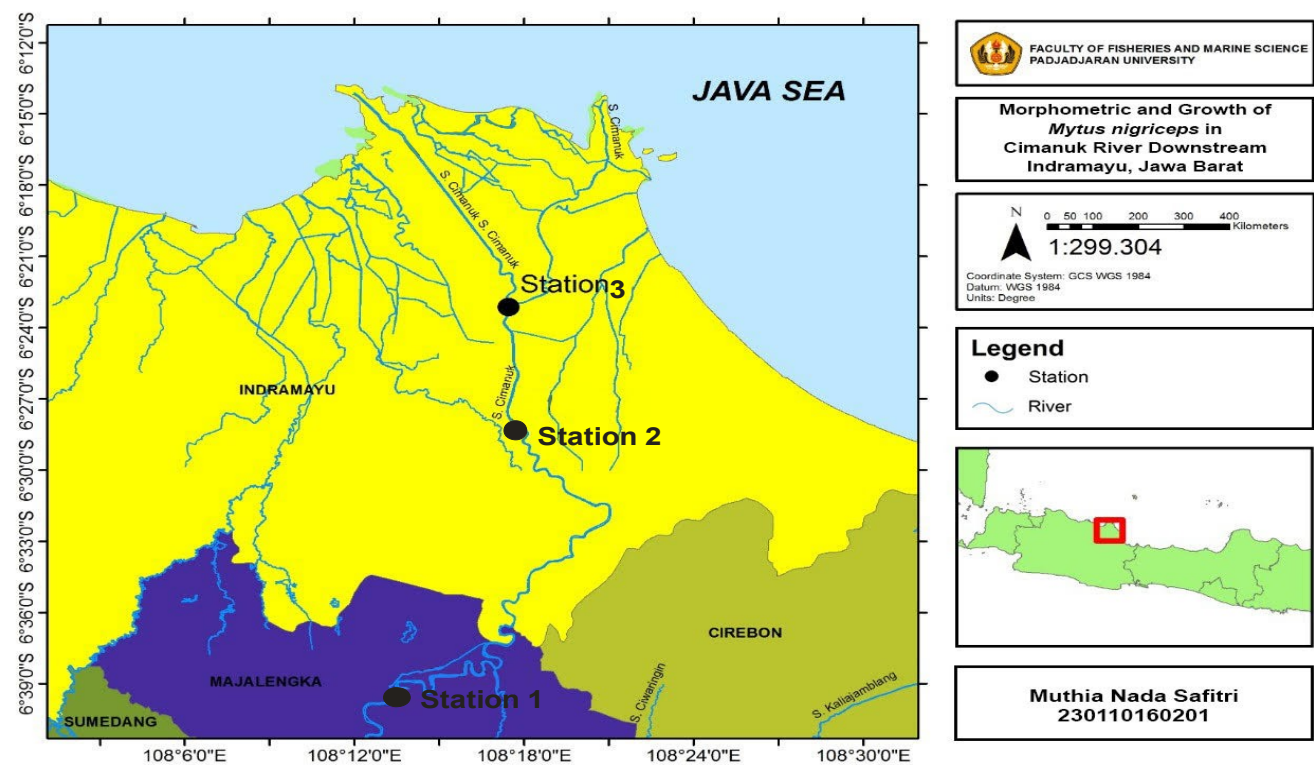

Gambar 1. Peta lokasi penelitian.

kematangan gonad dan kelimpahan makanan (King 1995). Penelitian ini bertujuan untuk mengetahui ciri morfometrik dan pola pertumbuhan ikan keting berdasarkan analisa hubungan panjang bobot dan faktor kondisi.

\section{METODE PENELITIAN}

\section{Lokasi Penelitian}

Penelitian ini dilaksanakan pada bulan Agustus 2020 sampai September 2020 di hilir Sungai Cimanuk Provinsi Jawa Barat. Lokasi pengambilan sampel ikan di tiga lokasi, yaitu:

Stasiun 1 (St.1): Desa Ujungjaya Kabupaten Sumedang pada koordinat $6^{\circ} 42^{\prime} 39^{\prime \prime} \mathrm{S}$ dan $108^{\circ} 05^{\prime} 18.7$ ' E

Stasiun 2 (St.2): Desa Palasari (perbatasan) Kabupaten Sumedang dengan Kabupaten Majalengka pada koordinat $6^{\circ} 44^{\prime} 57.5$ " S dan 10809’03.8” E, dan

Stasiun 3 (St.3): Desa Jatibarang Kabupaten Indramayu pada koordinat $6^{\circ} 28^{\prime} 01.7^{\prime \prime} \mathrm{S}$ dan $108^{\circ} 17^{\prime} 40.3 ”$ E (Gambar 1).

Pengukuran dan pengamatan sampel ikan dilakukan di Laboratorium Akuakultur
Fakultas Perikanan dan Ilmu Kelautan Universitas Padjadjaran.

\section{Pengambilan dan Pengamatan sampel}

Alat tangkap yang digunakan untuk pengambilan sampel adalah jala lempar dengan bukaan jala saat dioperasikan 4 meter, ukuran mata jaring 0,5 inci -1 inci, ikan dari tiap stasiun diambil dari pagi sampai siang. Ikan keting yang tertangkap sebanyak 84 ekor, yaitu 44 ekor dari Stasiun 1, 30 ekor dari Stasiun 2, dan 10 ekor dari Stasiun 3.

Bahan yang digunakan untuk pengukuran dan pengamatan sampel adalah ikan keting hasil tangkapan dan es batu untuk pengawet sampel saat pengangkutan dari lapangan. Alat yang digunakan adalah timbangan digital dengan ketelitian 0,01 g, penggaris, coolbox, alat tulis, dan kamera. Parameter yang diamati meliputi ciri morfometrik, hubungan panjang bobot, dan faktor kondisi. Hasil pengukuran dan pengamatan digunakan data primer yang disajikan dalam bentuk tabel dan grafik. Pengukuran ciri morfometrik dilakukan di Laboratorium Akuakultur Fakultas Perikanan 


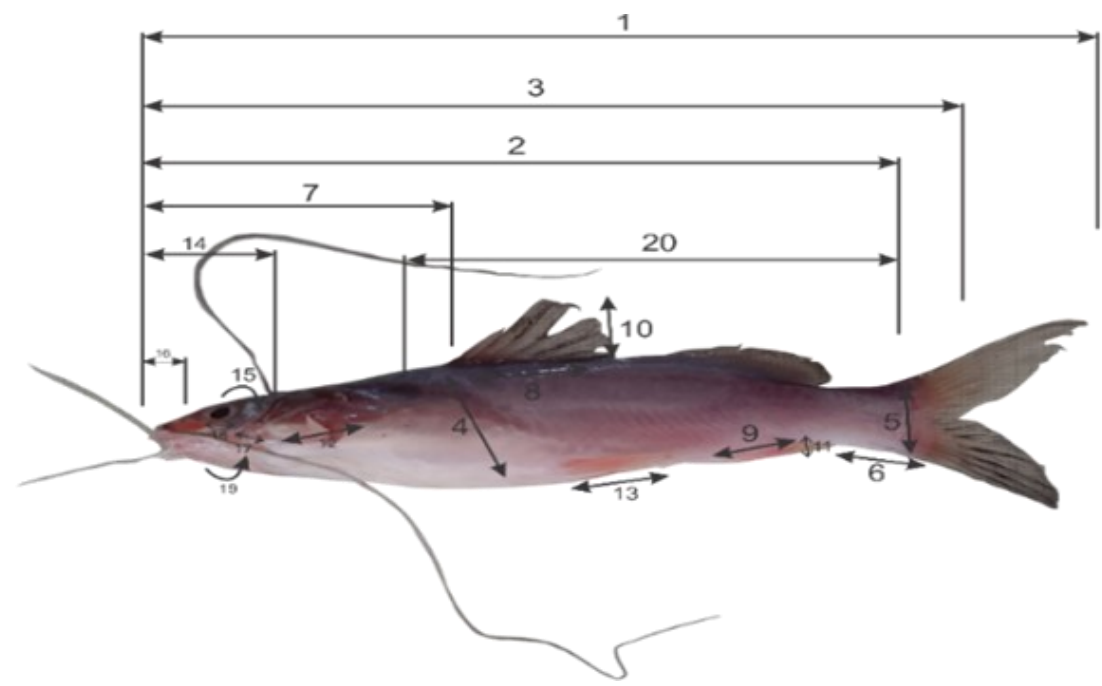

Keterangan: 1) Panjang Total (PT), 2) Panjang Baku (PB), 3) Panjang Cagak (PC), 4) Tinggi Tubuh (TT), 5) Tinggi Batang Ekor (TBE), 6) Panjang Pangkal Ekor (PPE), 7) Panjang Pre-dorsal (PPD), 8) Panjang Dasar Sirip Dorsal (PDSD), 9) Panjang Dasar Sirip Anal (PDSA), 10) Tinggi Sirip Dorsal (TSD), 11) Tinggi Sirip Anal (TSA), 12) Panjang Sirip Pektoral (PSP), 13) Panjang Sirip Anal (PSA), 14)Panjang Kepala (PK), 15) Lingkar Kepala (LK), 16) Panjang Hidung (PH), 17) Panjang Orbit Preopercle (POP), 18) Diameter Mata (DM), 19) Lebar Bukaan Mulut (LBM), 20) Linea Lateralis (LL)

Gambar 2. Bagian Ikan keting yang diukur.

Ilmu Kelautan Universitas Padjadjaran. Bagian tubuh yang diukur terdapat pada gambar 2 .

\section{Analisis Data}

Data karakteristik morfometrik yang diukur terdiri dari 20 karakteristik morfometrik, dihitung dengan cara melakukan standardisasi terhadap panjang baku, dilanjutkan dengan uji t Test (Nuryadi et al. 2017).

Analisis hubungan panjang bobot dilakukan untuk mengetahui pola pertumbuhan ikan keting, apakah pertambahan panjang ikan tersebut seimbang dengan pertambahan bobotnya (isometrik) atau pertumbuhannya tidak seimbang atau bersifat allometrik. Analisa hubungan panjang bobot menggunakan metode yang dikemukakan Effendie (2002) dan Herawati (2017) adalah sebagai berikut:

$$
\mathbf{W}=\mathbf{a} . \mathbf{L} \mathbf{b}
$$

\section{Keterangan:}

$\mathrm{W}=$ bobot ikan $(\mathrm{g})$,

$\mathrm{L}=$ panjang ikan $(\mathrm{mm})$

$\mathrm{a}$ dan $\mathrm{b}=$ konstanta
Selanjutnya untuk mengetahui ada tidaknya perbedaan nilai b (slope) digunakan uji t (t-test) pada taraf kepercayaan 95\% dengan hipotesis: $\mathrm{H} 0$ : Nilai $b=3$, pertumbuhan bersifat isometrik $\mathrm{H} 1$ : Nilai $b \neq 3$, pertumbuhan bersifat allometrik

Untuk pengujian nilai b dengan menggunakan uji t menggunakan rumus:

$$
\boldsymbol{t}=\left|\frac{3-b}{S_{h}}\right|
$$

Keterangan:

$\mathrm{t}=$ nilai $\mathrm{t}$ hitung;

$\mathrm{b}=$ slope;

$\mathrm{Sb}=$ standar deviasi

Jika didapatkan nilai $b=3$, maka pertambahan panjang seimbang dengan pertambahan bobot disebut pertumbuhan ikan isometrik. Jika Nilai $b<3$ maka pertambahan panjang lebih cepat dibandingkan dengan pertambahan bobot disebut pertumbuhan allometrik negatif. Jika nilai $b>3$ maka pertambahan bobot lebih cepat dibandingkan pertambahan panjangnya disebut pertumbuhan allometrik positif. 
Tabel 1. Interpretasi Nilai Korelasi (r).

\begin{tabular}{cc}
\hline Nilai Koefisian Korelasi & Arti \\
\hline $0,00-0,19$ & Korelasi sangat lemah \\
$0,20-0,39$ & Korelasi lemah \\
$0,40-0,69$ & Korelasi sedang \\
$0,70-0,89$ & Korelasi kuat \\
$0.90-1,00$ & Korelasi sangat kuat \\
\hline
\end{tabular}

Sumber : Biring (2017)

Analisis data hubungan panjang bobot didapatkan nilai korelasi (r). Nilai korelasi (r) untuk menunjukkan seberapa erat hubungan antara panjang dan bobot pada ikan. Menurut Biring (2011) interpretasi nilai korelasi (r) dapat dilihat pada Tabel 1.

Menurut Herawati (2017), perhitungan faktor kondisi atau indeks ponderal menggunakan sistem metrik (K). Mencari nilai $\mathrm{K}$ digunakan rumus:

$$
\mathbf{K}=\frac{\mathbf{W}}{\mathbf{a} \cdot \mathbf{L}^{\mathbf{b}}}
$$

Keterangan:

$\mathrm{K}$ = faktor kondisi

$\mathrm{W}=$ bobot ikan $(\mathrm{g})$

$\mathrm{L}$ = panjang total $(\mathrm{mm})$

$\mathrm{a}=$ intercept $; \mathrm{b}=$ slope

\section{HASIL DAN PEMBAHASAN}

\section{Morfometrik Ikan Keting}

Ukuran ikan adalah jarak antara satu bagian tubuh ke bagian tubuh yang lain. Setiap ikan mempunyai ukuran yang berbeda-beda tergantung pada umur, jenis kelamin, dan keadaan lingkungan hidupnya. Faktor-faktor lingkungan yang dapat mempengaruhi kehidupan ikan di antaranya adalah makanan, parameter kualitas air seperti kekeruhan, suhu, $\mathrm{pH}$, ammonia, dan salinitas. Faktor-faktor tersebut baik secara sendirisendiri maupun bersama-sama mempunyai pengaruh yang sangat besar terhadap pertumbuhan ikan. Nurmadinah (2016) melaporkan dua ekor ikan mempunyai umur yang sama, namun ukuran mutlak di antara keduanya dapat saling berbeda.

Hasil pengukuran dari seluruh stasiun pengambilan sampel (Tabel 2) adalah panjang total ikan keting di St.1 (Desa Ujungjaya Kabupaten Sumedang) berkisar antara 7,3 cm sampai $12,0 \mathrm{~cm}$, rata-rata $10,2 \mathrm{~cm}$, dengan persentase nilai rata-rata terhadap panjang baku sebesar $131,5 \% \pm 1,1$; di St. 2 (Desa Palasari perbatasan Kecamatan Ujungjaya dan Kecamatan Kertajati Kabupaten Majalengka) berkisar antara 10,1 cm sampai $17,2 \mathrm{~cm}$, rata-rata $14,0 \mathrm{~cm}$, dengan persentase nilai rata-rata terhadap panjang baku sebesar $120,9 \% \pm 2,1$; dan di St.3 berkisar antara $10,0 \mathrm{~cm}$ sampai $12,5 \mathrm{~cm}$, rata-rata $11,5 \mathrm{~cm}$, dengan persentase nilai rata-rata terhadap panjang baku sebesar $125,7 \% \pm 0,9$.

Ikan yang tertangkap dari St.3 hanya sebanyak 10 ekor sehingga tidak dilakukan perhitungan dikarenakan tidak memenuhi persyaratan pada perhitungan statistik, serta tidak mewakili jumlah populasi. Hal ini sesuai dengan pendapat Effendi (1997) dan Herawati (2017) bahwa jumlah sampel minimum adalah 30 ekor sehingga sampel ikan yang dibandingkan adalah ikan yang berasal dari St.1 dan St.2.

Hasil analisis dari 20 parameter ukuran (karakter morfometrik) organ terhadap persentase 
Tabel 2. Hasil Pengukuran Karakteristik Morfometrik Keting di Hilir Sungai Cimanuk (cm).

\begin{tabular}{|c|c|c|c|c|c|c|c|c|c|c|c|c|}
\hline \multirow[b]{2}{*}{$\begin{array}{l}\text { Karakteristik } \\
\quad(\mathrm{cm})\end{array}$} & \multicolumn{4}{|c|}{ Stasiun $1(n=44)$} & \multicolumn{4}{|c|}{ Stasiun $2(\mathrm{n}=30)$} & \multicolumn{4}{|c|}{ Strasiun $3(n=10)$} \\
\hline & Min & Maks & $\begin{array}{l}\text { Rata- } \\
\text { rata }\end{array}$ & $\begin{array}{c}\text { Rata-rata } \\
\text { terhadap } \\
\text { PB (\%) }\end{array}$ & Min & Maks & $\begin{array}{l}\text { Rata- } \\
\text { rata }\end{array}$ & $\begin{array}{l}\text { Rata-rata } \\
\text { terhadap } \\
\text { PB (\%) }\end{array}$ & Min & Maks & $\begin{array}{l}\text { Rata- } \\
\text { rata }\end{array}$ & $\begin{array}{l}\text { Rata-rata } \\
\text { terhadap } \\
\text { PB (\%) }\end{array}$ \\
\hline PT & 7,3 & 12,0 & 10,2 & $131,5 \pm 1,1$ & 10,1 & 17,2 & 14 & $120,9 \pm 2,1$ & 10 & 12,5 & 11,5 & $125,7 \pm 0,9$ \\
\hline PB & 5,5 & 9,0 & 7,7 & $100,0 \pm 0,9$ & 8,5 & 14,4 & 11,8 & $100,0 \pm 1,9$ & 8 & 10 & 9,2 & $100,0 \pm 0,7$ \\
\hline $\mathrm{PC}$ & 6,0 & 9,7 & 8,4 & $107,6 \pm 0,9$ & 8,9 & 15,1 & 12,3 & $105,2 \pm 1,8$ & 8,6 & 10,7 & 9,9 & $107,8 \pm 0,6$ \\
\hline TT & 1,1 & 1,8 & 1,5 & $19,5 \pm 0,2$ & 1,6 & 2,8 & 2,2 & $20,6 \pm 0,3$ & 2 & 2,5 & 2,3 & $24,6 \pm 0,3$ \\
\hline TBE & 0,7 & 1,2 & 1,0 & $13,0 \pm 0,1$ & 1,1 & 1,7 & 1,4 & $13,0 \pm 0,2$ & 1,2 & 1,5 & 1,4 & $15,5 \pm 0,1$ \\
\hline PPE & 1,1 & 1,8 & 1,5 & $19,2 \pm 0,2$ & 1,5 & 2,6 & 2 & $17,4 \pm 0,3$ & 1,5 & 1,9 & 1,7 & $18,6 \pm 0,2$ \\
\hline PPD & 2,2 & 3,6 & 3,1 & $39,2 \pm 0,3$ & 3,2 & 5,5 & 4,2 & $36,4 \pm 0,7$ & 3 & 3,7 & 3,5 & $37,8 \pm 0,2$ \\
\hline PDSD & 1,0 & 1,6 & 1,3 & $17,1 \pm 0,2$ & 1,4 & 2,1 & 1,6 & $14,9 \pm 0,2$ & 1,4 & 1,8 & 1,6 & $17,4 \pm 0,1$ \\
\hline PDSA & 0,7 & 1,1 & 0,9 & $11,6 \pm 0,1$ & 0,9 & 1,6 & 1,3 & $11,1 \pm 0,2$ & 1,0 & 1,3 & 1,1 & $12,2 \pm 0,1$ \\
\hline TSD & 1,1 & 1,7 & 1,4 & $19,8 \pm 0,2$ & 1,5 & 2,6 & 2,1 & $17,7 \pm 0,4$ & 1,4 & 1,8 & 1,6 & $17,6 \pm 0,1$ \\
\hline TSA & 0,8 & 1,4 & 1,1 & $14,6 \pm 0,2$ & 1,1 & 1,9 & 1,5 & $13,1 \pm 0,2$ & 1,2 & 1,5 & 1,3 & $14,6 \pm 0,1$ \\
\hline PSP & 1,0 & 1,7 & 1,5 & $18,8 \pm 0,2$ & 1,5 & 2,6 & 2 & $17,8 \pm 0,3$ & 1,5 & 1,9 & 1,7 & $19,0 \pm 0,1$ \\
\hline PSA & 0,9 & 1,4 & 1,2 & $15,1 \pm 0,1$ & 1,1 & 1,9 & 1,6 & $13,9 \pm 0,2$ & 1,2 & 1,5 & 1,4 & $15,0 \pm 0,1$ \\
\hline PK & 1,3 & 2,2 & 1,8 & $11,9 \pm 0,2$ & 1,8 & 3,1 & 2,5 & $21,8 \pm 0,4$ & 1,8 & 2,3 & 2,1 & $22,6 \pm 0,2$ \\
\hline LK & 3,3 & 5,5 & 4,5 & $58,6 \pm 0,6$ & 4,4 & 6,8 & 5,9 & $53,8 \pm 0,7$ & 5,1 & 6,4 & 5,8 & $64,0 \pm 0,5$ \\
\hline $\mathrm{PH}$ & 0,4 & 0,6 & 0,5 & $6,9 \pm 0,1$ & 0,5 & 0,8 & 0,7 & $6,3 \pm 0,1$ & 0,6 & 0,8 & 0,7 & $7,5 \pm 0,1$ \\
\hline POP & 0,7 & 1,2 & 1,0 & $12,9 \pm 0,1$ & 1 & 1,6 & 1,3 & $9,8 \pm 0,4$ & 0,5 & 0,8 & 0,6 & $6,6 \pm 0,1$ \\
\hline $\mathrm{DM}$ & 0,3 & 0,5 & 0,4 & $5,7 \pm 0,1$ & 0,3 & 0,6 & 0,5 & $4,4 \pm 0,1$ & 0,4 & 0,5 & 0,5 & $5,1 \pm 0,05$ \\
\hline LBM & 0,7 & 1,2 & 1,0 & $12,6 \pm 0,1$ & 1 & 1,6 & 1,3 & $10,3 \pm 0,3$ & 0,7 & 0,9 & 0,8 & $8,5 \pm 0,1$ \\
\hline LL & 4,0 & 6,7 & 5,8 & $81,1 \pm 2,6$ & 5,8 & 9,5 & 7,9 & $68,4 \pm 1,1$ & 5,7 & 7,3 & 6,6 & $72,5 \pm 0,6$ \\
\hline
\end{tabular}

Keterangan: Min $=$ Minimum; Maks $=$ maksimum

panjang baku menunjukkan bahwa ikan keting yang terdapat di St.1 dan St.2 sebagai berikut: t-Test: Two-Sample Assuming Unequal Variances

\begin{tabular}{lcc}
\hline & Stasiun 1 & Stasiun 2 \\
\hline Mean & 35,83 & 33,85 \\
Variance & 1464,65 & 1297,94 \\
Observations & 20 & 20 \\
Hypothesized Mean & 0 & \\
Difference & 38 & \\
df & 0,17 & \\
t Stat & 0,43 & \\
P $(\mathrm{T}<=$ t) one-tail & 1,69 & \\
t Critical one-tail & 0,87 & \\
P $(\mathrm{T}<=$ t) two-tail & 2,02 & \\
t Critical two-tail &
\end{tabular}

Berdasarkan hasil uji t (independent sample t-test), tstat < tcrit menunjukkan bahwa keting yang tertangkap di St.1 memiliki karakteristik morfometrik yang sama dengan keting di St.2.

Ciri meristik ikan keting, yaitu pada sirip punggung memiliki satu jari-jari keras enam sampai delapan jari-jari lunak (D.I.6-8), sirip dada satu jari-jari keras tujuh sampai sebelas jari-jari lunak (P.I.7-11), sirip perut enam sampai sepuluh jari-jari lunak (V.6-10), sirip dubur sembilan sampai sebelas jari-jari lunak (A.9-11), dan sirip ekor lima belas sampai dua puluh dua jari-jari lunak (C.15-22). 


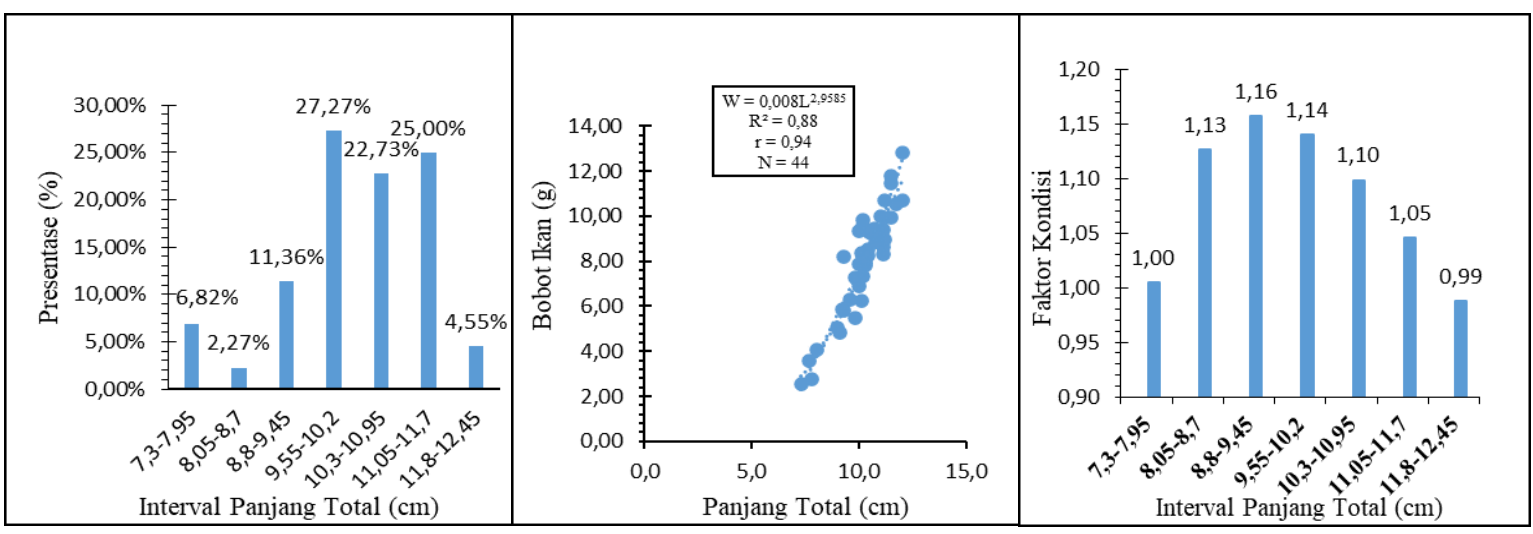

(a) Distribusi Ukuran Ikan Keting (b) Pertumbuhan Ikan Keting (cm)

Gambar 3. (a) Distribusi Ukuran, (b) Pertumbuhan, dan (c) Faktor Kondisi Ikan Keting di Stasiun 1

Pertumbuhan Ikan Keting di Hilir Sungai Cimanuk

\section{Pertumbuhan ikan keting di Stasiun 1}

Ikan keting yang tertangkap di St.1 memiliki panjang total bervariasi antara 7,3 cm sampai $12,0 \mathrm{~cm}$ dan berat antara 2,5 $\mathrm{g}$ sampai 12,8 g. Hasil perhitungan menggunakan metode distribusi frekuensi, diperoleh tujuh kelompok ukuran. Jumlah ikan keting yang banyak tertangkap pada interval panjang total antara 9,55 $\mathrm{cm}$ sampai 10,2 $\mathrm{cm}$ dengan persentase $27,27 \%$ dan ikan keting yang paling sedikit tertangkap berukuran antara $8,05 \mathrm{~cm}$ sampai $8,70 \mathrm{~cm}$ dengan persentase 2,27\% (Gambar 3a).

Hasil perhitungan hubungan panjang bobot diperoleh persamaan regresi $\mathrm{W}=0,008 \mathrm{~L}^{2,958}$ (Gambar 3b). Nilai slope (b) sebesar 2,958 (kurang dari 3) artinya pertumbuhan ikan keting bersifat allometrik negatif, yaitu pertambahan panjang lebih cepat dari pada pertambahan bobotnya. Pada persamaan tersebut diperoleh nilai regesi (R2) sebesar 0,8844 artinya sebesar $88,44 \%$ pertambahan bobot ikan keting dipengaruhi oleh pertambahan panjangnya dan 11,56\% dipengaruhi oleh faktor lain. Nilai korelasi (r) didapatkan sebesar 0,9404 artinya panjang dan bobot ikan keting memiliki hubungan yang sangat kuat.

Faktor kondisi (K) ikan keting berkisar antara 0,99 sampai 1,16 dengan nilai rata-rata sebesar 1,08 (Gambar 3c). Ikan keting yang memiliki faktor kondisi terbaik diperoleh pada ikan berukuran panjang total antara $8,8 \mathrm{~cm}$ sampai 9,45 cm; selanjutnya untuk ikan keting yang berukuran panjang total lebih dari 9,45 cm memiliki kecenderungan faktor kondisi menurun. Ikan keting yang memiliki faktor kondisi terendah $\mathrm{K}=0,99$ ditemukan pada ikan berukuran panjang total antara $11,8 \mathrm{~cm}$ sampai $12,45 \mathrm{~cm}$.

\section{Pertumbuhan Ikan keting di stasiun 2}

Ikan keting yang tertangkap di Stasiun 2 memiliki panjang total bervariasi antara 10,0 cm sampai 17,20 $\mathrm{cm}$ dan berat antara 10,4 g29,6 g. Hasil perhitungan menggunakan metode distribusi frekuensi diperoleh lima kelompok ukuran. Jumlah ikan keting yang banyak tertangkap pada interval panjang total antara $11,5 \mathrm{~cm}-12,9 \mathrm{~cm}$ dengan prosentase 33,33\% dan ikan keting yang paling sedikit tertangkap berukuran antara 13,0 sampai 14,4 


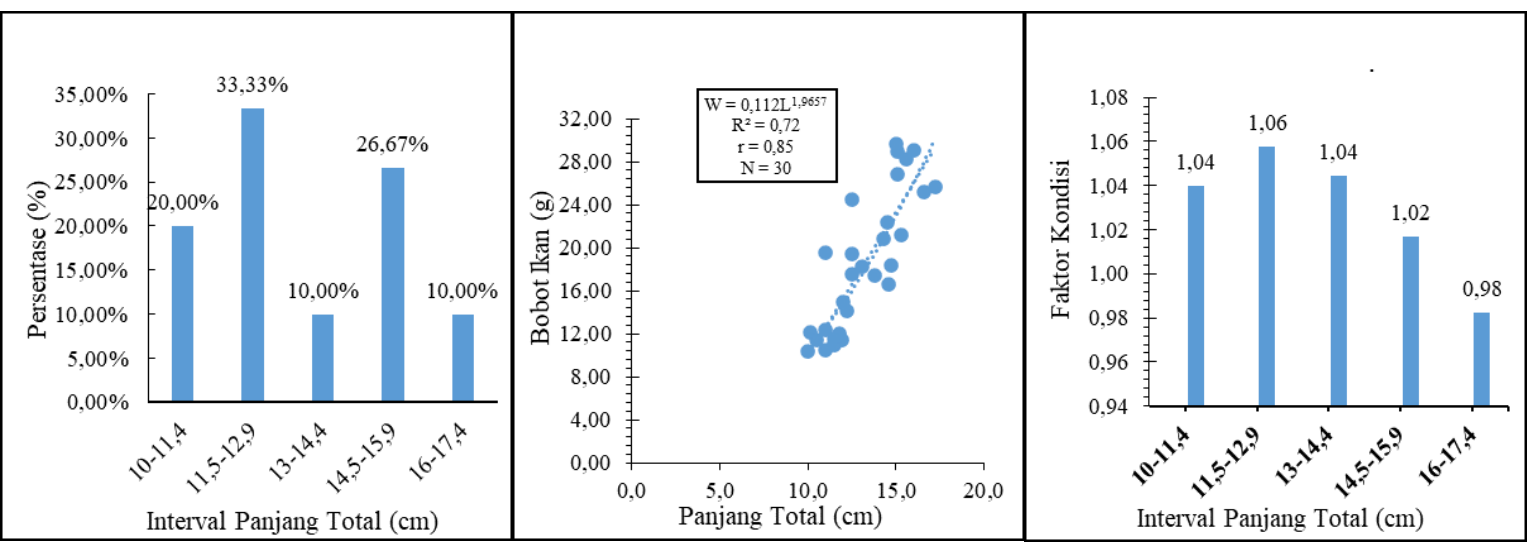

(a) Distribusi Ukuran Ikan Keting (cm)

(b) Pertumbuhan Ikan Keting

Gambar 4. (a) Distribusi Ukuran, (b) Pertumbuhan, dan (c) Faktor Kondisi Ikan Keting di Stasiun 2

$\mathrm{cm}$ dan $16,0 \mathrm{~cm}$ sampai $17,4 \mathrm{~cm}$ dengan presentase $10,0 \%$ (Gambar $4 a)$.

Hasil perhitungan hubungan panjang bobot diperoleh persamaan regresi $\mathrm{W}=$ $0,112 \mathrm{~L}^{1,957}$ (Gambar 4b). Nilai slope (b) sebesar 1,957 (nilai b kurang dari 3) artinya pertumbuhan ikan keting bersifat allometrik negatif, yakni pertambahan panjang lebih cepat dari pada pertambahan bobotnya. Pada persamaan tersebut diperoleh nilai regesi $\left(\mathrm{R}^{2}\right)$ sebesar 0,7239 artinya sebesar $72,39 \%$ pertambahan bobot ikan keting dipengaruhi oleh pertambahan panjangnya dan $27,61 \%$ dipengaruhi oleh faktor lain. Nilai korelasi (r) didapatkan sebesar 0,85080 artinya panjang dan bobot ikan keting memiliki hubungan yang sangat kuat.

Faktor kondisi (K) ikan keting berkisar antara 0,98 sampai 1,06 dengan nilai rata-rata sebesar 1,08 (Gambar 4c). Ikan keting yang memiliki faktor kondisi terbaik diperoleh pada ikan berukuran panjang total antara $11,5 \mathrm{~cm}$ sampai $12,9 \mathrm{~cm}$; selanjutnya untuk ikan keting yang berukuran panjang total lebih dari 12,9 $\mathrm{cm}$ memiliki tren penurunan faktor kondisi. Ikan keting yang memiliki faktor kondisi terendah $\mathrm{K}=0,98$ ditemukan pada ikan berukuran panjang total antara $16,0 \mathrm{~cm}$ sampai $17,4 \mathrm{~cm}$.

Ikan keting yang hidup di hilir Sungai Cimanuk memiliki pola pertumbuhan allometrik negatif, yaitu pertambahan panjang lebih cepat dari pada bobotnya, akan tetapi ada perbedaan di dalam faktor kondisi. Ikan keting yang hidup di St.1 (perairan sungai Cimanuk di Desa Ujungjaya Kabupaten Sumedang memiliki rata-rata faktor kondisi lebih baik $(\mathrm{K}=1,08)$ dibandingkan dengan ikan keting yang hidup di St.2 (perairan sungai Cimanuk di Desa Palasari (perbatasan) Kabupaten Sumedang dan Kabupaten Majalengka $(\mathrm{K}=1,03)$ (Tabel 4). Adanya perbedaan tersebut disebabkan adanya faktor luar yang mempengaruhi pertumbuhan ikan keting di Stasiun 2, yaitu sebesar 27,61\% (Gambar 4b). Hal ini diduga karena ada parameter kualitas air yang telah melebihi baku mutu perairan untuk perikanan diantaranya kandungan total suspended solid $1.110 \mathrm{mgL}^{-1}$ dan kadar ammonia sebesar 0,45 $\mathrm{mgL}^{-1}$ bila dibandingkan dengan di Stasiun 1 (Tabel 3).

Ikan keting yang hidup di Sungai Cimanuk memiliki pola pertumbuhan yang berbeda dengan ikan keting yang hidup di 
Tabel 3. Kualitas Perairan di Hilir Sungai Cimanuk.

\begin{tabular}{lclllll}
\hline \multicolumn{1}{c}{ Parameter } & Satuan & Stasiun 1 & Stasiun 2 & Stasiun 3 & kelas II* $^{\text {kelas III* }}$ \\
\hline Suhu & ${ }^{\circ} \mathrm{C}$ & 28,1 & 28,4 & 27,4 & Deviasi 3 & Deviasi $3^{\circ}$ \\
Transparansi & $\mathrm{Cm}$ & 32 & 29 & 27 & - & - \\
Cahaya & - & 7,3 & 8,16 & 7,45 & $6-9$ & $6-9$ \\
$\mathrm{pH}$ & $\mathrm{mgL}^{-1}$ & 16,7 & 20,2 & 12,5 & 25 & - \\
$\mathrm{CO}_{2}$ & $\mathrm{mgL}^{-1}$ & 58,3 & 69,5 & 51,2 & $<500$ & - \\
$\mathrm{HCO}$ & $\mathrm{mgL}^{-1}$ & 7 & 6,5 & 7,2 & $>4$ & $>3$ \\
$\mathrm{DO}$ & $\mathrm{mgL}^{-1}$ & 27 & 78 & 68 & 25 & 50 \\
$\mathrm{COD}$ & $\mathrm{mgL}^{-1}$ & 234 & 1110 & 488 & 50 & 400 \\
$\mathrm{TSS}$ & $\mathrm{mgL}^{-1}$ & 166 & 175 & 149 & 1000 & 1000 \\
TDS & $\mathrm{mgL}^{-1}$ & 0,386 & 0,445 & 0,227 & $<0,02$ & - \\
Ammonia & $\mathrm{Ppt}$ & 0 & 0 & 0 & - & - \\
Total & Salinitas & &
\end{tabular}

Sumber: Herawati et al. (2020); (*) Baku mutu kualitas air PP No. 82 Tahun 2001.

Sungai Kampar Kiri dan Sungai Kampar Kanan. Syafrialdi et al. (2020) menyatakan bahwa ikan keting di Sungai Kampar memiliki pola pertumbuhan allometrik posistif, yaitu pertambahan bobot lebih cepat dari pada pertambahan panjangnya dengan nilai $\mathrm{K}$ antara 3,47 sampai 4,62 (Tabel 4).

Adanya perbedaan pola pertumbuhan ikan keting yang hidup di Sungai Cimanuk pada Stasiun 1 dan Stasiun 2 dengan yang hidup di Sungai Kampar Kanan dan Sungai Kampar Kiri menunjukkan bahwa pertumbuhan bersifat relatif, artinya dapat dimungkinkan berbeda menurut habitat dan waktu. Apabila terjadi perubahan terhadap lingkungan dan ketersediaan makanan, diperkirakan nilai hubungan panjang dan bobot juga akan berubah. Pada dasarnya pertumbuhan allometrik bersifat sementara, misalnya karena pertumbuhan yang berhubungan dengan kematangan gonad, sedangkan pertumbuhan isometrik merupakan secara terus menerus yang bersifat proporsional (Effendie 2002).

Faktor kondisi (K) ikan keting pada Stasiun 2 menunjukkan nilai $0,98-1,06$ dengan nilai rata-rata sebesar 1,03 . Nilai faktor kondisi ikan keting terendah terdapat pada ikan berukuran panjang total antara $16 \mathrm{~cm}$ sampai $17,4 \mathrm{~cm}$, sebesar 0,98 , dan nilai faktor kondisi tertinggi terdapat pada ikan berukuran antara 11,5 cm sampai 12,9 cm sebesar 1,06.

Menurut Syafrialdi et al. (2020) rata-rata nilai K populasi ikan keting di Sungai Kampar Kanan sebesar 3,37 dengan interval nilai $\mathrm{K}$ 3,29 sampai 3,45 dan rata-rata nilai $\mathrm{K}$ Sungai Kampar Kiri adalah 4,62 dengan interval 4,31

Tabel 4. Perbandingan Hubungan Panjang Bobot dan Faktor Kondisi Ikan Keting di Stasiun 1 dan Stasiun 2 dengan ikan keting di Sungai Kampar Kanan dan Kampar Kiri.

\begin{tabular}{lcccccc}
\hline \multicolumn{1}{c}{ Lokasi } & $\mathrm{n}$ & $\mathrm{b}$ & $\mathrm{r}$ & $\mathrm{R}^{2}$ & $\mathrm{~K}$ & $\mathrm{~W}=\mathrm{aL}^{\mathrm{b}}$ \\
\hline Stasiun 1 & 44 & 2,958 & 0,9404 & 0,8844 & 1,08 & $\mathrm{~W}=0,008 \mathrm{~L}^{2,958}$ \\
Stasiun 2 & 30 & 1,9657 & 0,8508 & 0,7239 & 1,03 & $\mathrm{~W}=0,112 \mathrm{~L}^{1,9657}$ \\
S. Kampar Kanan * & 202 & 3,393 & 0,894 & 0,859 & 3,37 & $\mathrm{~W}=0,0025 \mathrm{~L}^{3,393}$ \\
S. Kampar Kiri* & 212 & 3,256 & 0,949 & 0,908 & 4,62 & $\mathrm{~W}=0,0034 \mathrm{~L}^{3,256}$ \\
\hline
\end{tabular}

$\mathrm{n}=$ Jumlah sampel, $\mathrm{b}=$ Slope, $\mathrm{r}=$ Koefisien korelasi, $\mathrm{R}^{2}=$ Koefisien determinasi, $\mathrm{K}=$ Faktor kondisi

*Sumber: Syafrialdi et al. (2020) 
sampai 4,74. Dengan demikian nilai faktor kondisi ikan keting Stasiun 1 dan Stasiun 2 menunjukkan perbedaan yang sangat signifikan dengan ikan keting di Sungai Kampar Kanan dan Sungai Kampar Kiri. Ukuran ikan keting di hilir Sungai Cimanuk pada Stasiun 1 dan 2 lebih kecil dibandingkan dengan ikan keting di Sungai Kampar. Selanjutnya, Syafrialdi et al. (2020) menyatakan bahwa ikan keting di Sungai kampar memiliki nilai $\mathrm{K}$ yang besar pada spesies ikan keting betina dibandingkan spesies ikan keting jantan. Pada penelitian ini, tidak membandingkan pola pertumbuhan antara ikan jantan dan betina.

Nilai K sangat berkorelasi dengan hubungan panjang bobot begitu juga dengan nilai $b$ sangat penting untuk menilai kondisi spesies ikan dalam kondisi baik. Faktor kondisi ikan keting di Hilir Sungai Cimanuk menunjukkan kondisi yang cenderung baik karena berkisar antara 1-3, adapun nilai faktor kondisi di interval tertentu pada Stasiun $1=0,99$ dan Stasiun $2=$ 0,98 hampir mendekati angka 1 . Hal tersebut sesuai dengan pernyataan Effendie (2002), yaitu bila nilai $\mathrm{K}$ yang berkisar antara 1-3 mengindikasikan keadaan yang baik dan tergolong ikan yang bentuk badannya kurang pipih. Berdasarkan hasil analisis statistik bahwa keting di St.1 memiliki kesamaan karakteristik morfometrik dengan keting di St.2, artinya persediaan makanan cukup.

\section{KESIMPULAN}

Keting yang tertangkap di hilir Sungai Cimanuk, di Desa Ujungjaya Kabupaten Sumedang dan di Desa Palasari perbatasan Kecamatan Ujungjaya dan Kecamatan Kertajati Kabupaten Majalengka memiliki karakteristik morfometrik sama dan pola pertumbuhan bersifat allometrik negatif.
Faktor kondisi ikan keting memperlihatkan baik dengan nilai $\mathrm{K}$ berkisar antara 0,98-1,16. Pertumbuhan ikan keting di Stasiun 1 relatif lebih besar dibandingkan dengan pertumbuhan ikan keting di Stasiun 2. Data riset ini dapat digunakan sebagai upaya pengelolaan ikan keting di Sungai Cimanuk.

\section{UCAPAN TERIMA KASIH}

Penulis menyampaikan ucapan terima kasih kepada Fakultas Perikanan dan Ilmu Kelautan Universitas Padjadjaran yang telah memberikan izin melakukan riset dan fasilitas laboratorium, Direktorat Riset dan Pengabdian pada Masyarakat yang telah memberikan dana melalui skema riset Nomor 11/E1/KPT/2021 tanggal 01 Februari 2021 sehingga riset ini berjalan dengan lancar.

\section{DAFTAR PUSTAKA}

Affandi, R., Sjafei, S.D., Raharjo, M. F., \& Sulistiono. (1992). Iktiologi. Bogor: Institut Pertanian Bogor.

Biring, D. (2011). Hubungan Bobot Panjang dan Faktor Kondisi Ikan Pari (Dasyatis kuhlii, Muller \& Henle, 1841) yang didaratkan di Tempat Pelelangan Ikan Paotere Makassar Sulawesi Selatan. [Skripsi]. Program Studi Manajemen Sumberdaya Perairan. Fakultas Ilmu Kelautan dan Perikanan. Universitas Hasanuddin.

Effendie, M.I. (1997). Metode Biologi Perikanan. Bogor: Penerbit Yayasan Dewi Sri.

Effendi, M.I. (2002). Biologi Perikanan. Yogyakarta: Penerbit Yayasan Pustaka Utama.

Froese, R. \& Pauly, D. (2021). Mystus nigriceps (Valenciennes, 1840). [FishBase]. Diambil dari https:// www.fishbase.de/summary/Mystus- 
nigriceps.html [17 Juni 2021].

Haryono. (2017). Fauna Ikan Air Tawar di Perairan Kawasan Gunung Sawal, Jawa Barat, Indonesia. Berita Biologi, 16(2), 147-156. DOI: 10.14203/ beritabiologi.v16i2.2186

Herawati, T. (2017). Metode Biologi Perikanan. Bandung: Unpad Press.

Herawati, T., Rohman, A., \& Dewantoro, G. (2019). Jenis Ikan Air Tawar Di Jawa Barat dan Status Perlindungannya. Bandung: Unpad Press.

Herawati, T. \& Sidik, R.A.R. (2020). Struktur Komunitas Ikan di Hilir Sungai Cimanuk Provinsi Jawa Barat pada Musim Penghujan. Jurnal Perikanan Universitas Gadjah Mada 22(2), 113122. DOI $10.22146 /$ jfs. 47655

King, M. (1995). Fishery Biology: Assessment and Management. Fishing News Book. United Kingdom

Kottelat, M., Whiten, A.J., Kartikasari, S.N., \& Wirjoatmodjo, S. (1993). Freshwater fishes of Western Indonesia and Sulawesi. Periplus Editions (HK) Ltd. Singapore

$\mathrm{Ng}$, H.H. (2002). The identity of Mystus nigriceps (Valenciennes in Cuvier \& Valenciennes, 1840), with the description of a new bagrid catfish (Teleostei: Siluriformes) from Southeast Asia. The Raffles Bulletin of Zoology, 50(1), 161-168.

Ng, H.H. (2019). Mystus nigriceps (Valenciennes, 1840). The IUCN Red List of Threatened Species 2019. Diambil dari https://doi.org/10.2305/ IUCN.UK.2019-3.RLTS [25 Januari 2021]. Nurmadinah. (2016). Studi Ciri Morfometrik dan Meristik Ikan Penja Asal Polewali Mandar dan Ikan Nike (Awaous melanocephalus) Asal Gorontalo.
[Skripsi]. Fakultas Sains dan Teknologi. UIN Alauddin Makassar.

Nuryadi., Astuti, T.D., Utami, E.S., \& Budiantara, M. (2017). Dasar-Dasar Statistik Penelitian. Yogyakarta: Penerbit Sibuku Media.

Riede, K. (2004). Global register of migratory species - from global to regional scales. Dalam Froese, R. \& Pauly, D. (2021). Mystus nigriceps (Valenciennes, 1840). [FishBase]. Diambil dari https://www.fishbase.de/ summary/Mystus-nigriceps.html [17 Juni 2021].

Riehl, R. \& Baensch, H.A. (1991). Aquarien Atlas. Band. 1. Dalam Froese, R. \& Pauly, D. (2021). Mystus nigriceps (Valenciennes, 1840). [FishBase] Diambil dari https://www.fishbase.de/ summary/Mystus-nigriceps.html [17 Juni 2021].

Sjafei, D.S., Wirjoatmodjo, S., Rahardjo, M.F., \& Susilo, S.B. 2001. Fauna Ikan di Sungai Cimanuk, Jawa Barat. Jurnal Iktiologi Indonesia, 1(1), 1-6. https://doi.org/10.32491/jii.v1i1.149

Surawijaya, A. (2004). Studi Morfologi Beberapa Jenis Ikan Lalawak (Barbodes spp.) di Sungai Cikandung dan Kolam Budidaya Kecamatan Buah Dua Kabupaten Sumedang. [Skripsi]. Bogor: Institut Pertanian Bogor.

Syafrialdi, Dahelmi, Roesma, D.I., \& Syandri, H. (2020). Length-Weight Relationship and Condition Factor of Two-Spot Catfish Mystus nigriceps (Valenciennes, 1840) (Pisces, Bagridae) from kampar Kanan River and kampar Kiri River in Indonesia. Pakistan Journal of Biological Sciences, 23(12), 1636-1642. doi: 10.3923/pjbs.2020.1636.1642 